\title{
Correction to: Genomic landscape of small cell carcinoma of the breast contrasted to small cell carcinoma of the lung
}

Brennan McCullar ${ }^{1}\left[\right.$ D Manjari Pandey ${ }^{1} \cdot$ George Yaghmour $^{1} \cdot$ Felicia Hare $^{1} \cdot$ Kruti Patel $^{1} \cdot$ Matthew K. Stein $^{1}$. Rebecca Feldman ${ }^{1}$. Jason C. Chandler ${ }^{1} \cdot$ Michael G. Martin ${ }^{1}$

Published online: 11 October 2018

(c) Springer Science+Business Media, LLC, part of Springer Nature 2018

Correction to: Breast Cancer Res Treat (2016) 158:195-202 https://doi.org/10.1007/s10549-016-3867-z

In the original publication, the sixth author name was published incorrectly as Matthew Stein. The correct author name should read as Matthew K Stein.

The original article can be found online at https://doi.org/10.1007/ s10549-016-3867-z.

Brennan McCullar

bpalazo@gmail.com

1 University of Tennessee Health Science Center, Memphis,

TN, USA 